\title{
Portuguese School Libraries Best Practices Crossing Borders
}

\author{
Isabel Mendinhos \\ School Libraries Network, Portugal
}

\begin{abstract}
In Portugal, the School Libraries Network program (SLN) has been promoting and sharing best practices through the Web as a way to illustrate the excellent work many libraries do and to inspire others that are in different development stages. These are innovative, consistent, systematic and proven experiences, able to reveal the full use of library resources and potential beyond the four walls of classrooms and the boundaries of schools. The projects and activities focus on different areas: reading, information, media, ICT, curriculum collaboration..., and are disseminated through short videos, synopses, and supporting materials. The work done by the Portuguese school libraries has undoubtedly influenced the progression of reading, evidenced in the recent PISA results (2015). Three years after extensive promotion of these good examples, we can conclude that this has been one of the most effective SLN strategies for the ongoing development of libraries and their impact on learning.
\end{abstract}

\section{Keywords: School Libraries, Portugal, Best Practices, Strategies, Dissemination, Impact \\ INTRODUCTION}

The School Libraries Network has been growing in Portugal since 1996. Throughout the country, there are school libraries with good or excellent conditions and the coverage is almost complete. They have been installed in the schools of all levels of basic education, with the exception of cases where there isn't a room with the minimum required area.

Since 2006 the legislation concerning school libraries contemplates the existence of teacher librarians. So, in each school cluster there can be one, two or three teacher librarians. These are teachers who must have training in the area of school librarianship and technology and who are legally obliged to update their professional training each year.

This situation has allowed SLN to focus on the quality of school library work. School libraries with excellent programs and projects are distinguished with a stamp of quality - worthy ideas - and given extra financial support.

In 2013 the SLN began to disseminate best practices in its webpage, which has proved to be an effective strategy to motivate other school libraries to adopt them with the necessary adaptations to their contexts.

Together with the existence of teacher librarians and of clear, coherent and demanding guiding documents, this initiative has contributed to an increasing importance of libraries in schools, due to their impact on reading habits and learning.

\section{Reading and Literacy - Historical Perspective}

In 1974, when the Portuguese revolution (the Carnation Revolution) put an end to over 40 years of an authoritarian dictatorship, Portugal was in a very poor condition from several points of view, namely in what concerned its illiteracy rate. In the beginning of the seventies, education was mandatory only until the $6^{\text {th }}$ grade and in the previous decades it was even worse.

After the revolution, an enormous effort was made to bring every child to school and to enlarge free compulsory education to the $9^{\text {th }}$ grade. Presently, it is compulsory until the $12^{\text {th }}$ grade.

Table 1. Illiteracy rate evolution: 1960-2011 


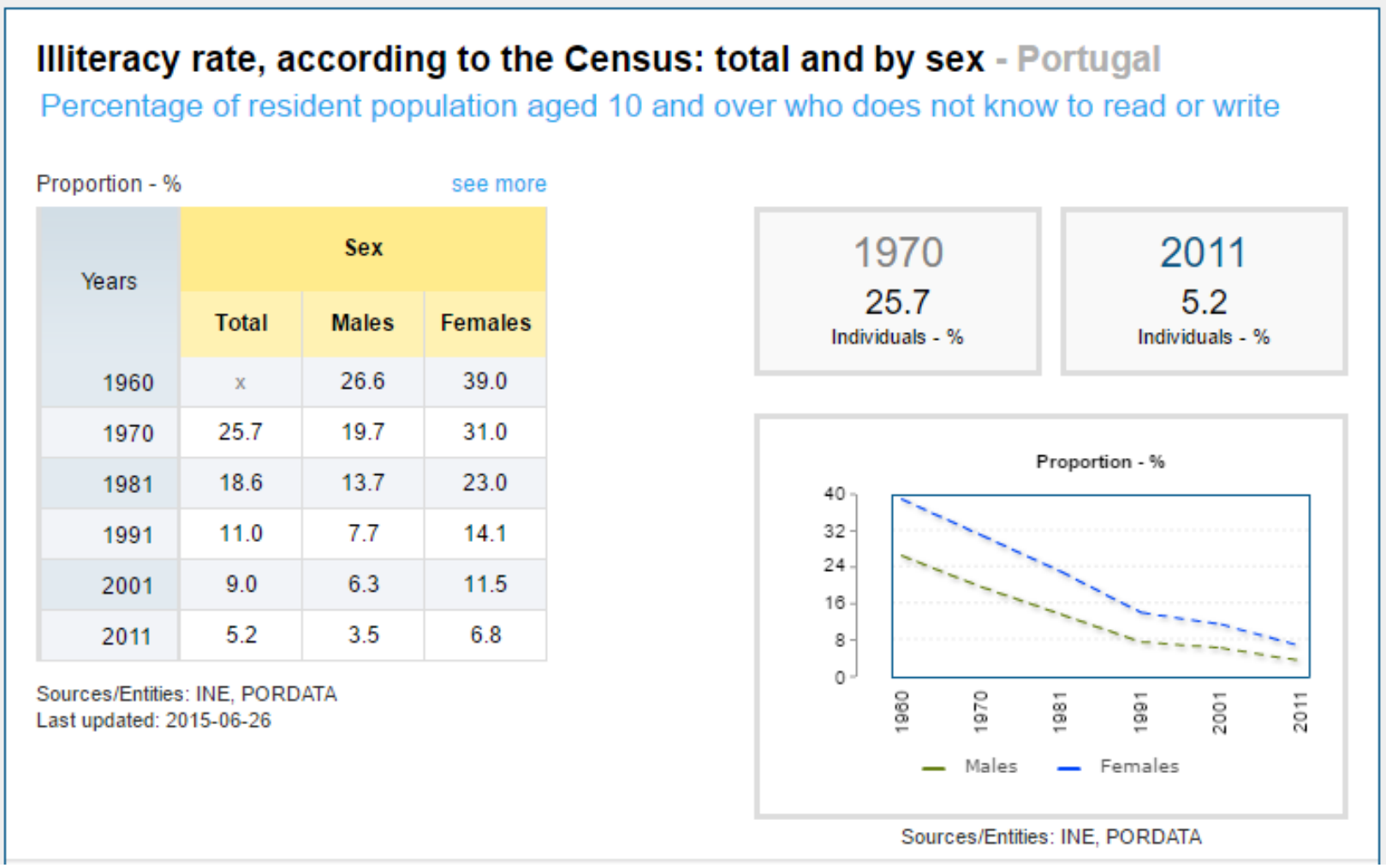

It has been a rewarding effort, but there is still a lot of work to be done.

Twelve years after the revolution the Public Libraries Network was created and 10 years later, in 1996, the SLN was born. Another 10 years passed and the country was still in need of dealing with the lack of reading habits of the population. The National Reading Plan was then created and school libraries were the structures than guaranteed its implementation in schools.

These measures are considered by the OECD Pisa experts to be important factors in the progress of Portuguese results in recent PISA tests (2015), in which the Portuguese students succeeded in exceeding significantly, for the first time, the average of OECD countries and stood out among those with best performances in reading.

This was very encouraging and means that we have to carry on and improve the work of school libraries. The National Reading Plan was extended for another 10 years and with a wider target now: besides K12 schools, university students and adult population.

Chart 1. The position of Portugal in OECD PISA 2015 


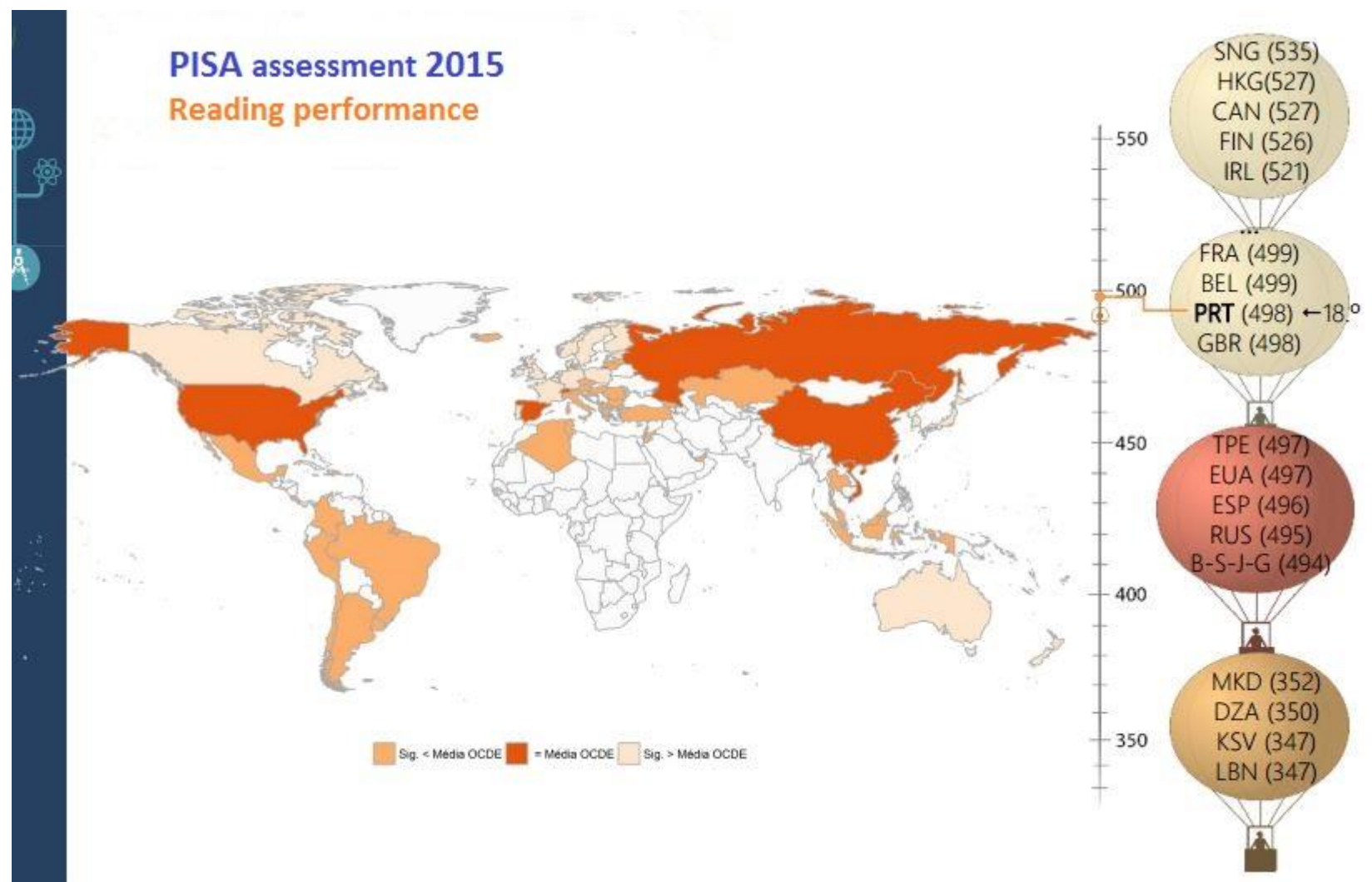

Chart 2. Evolution in reading

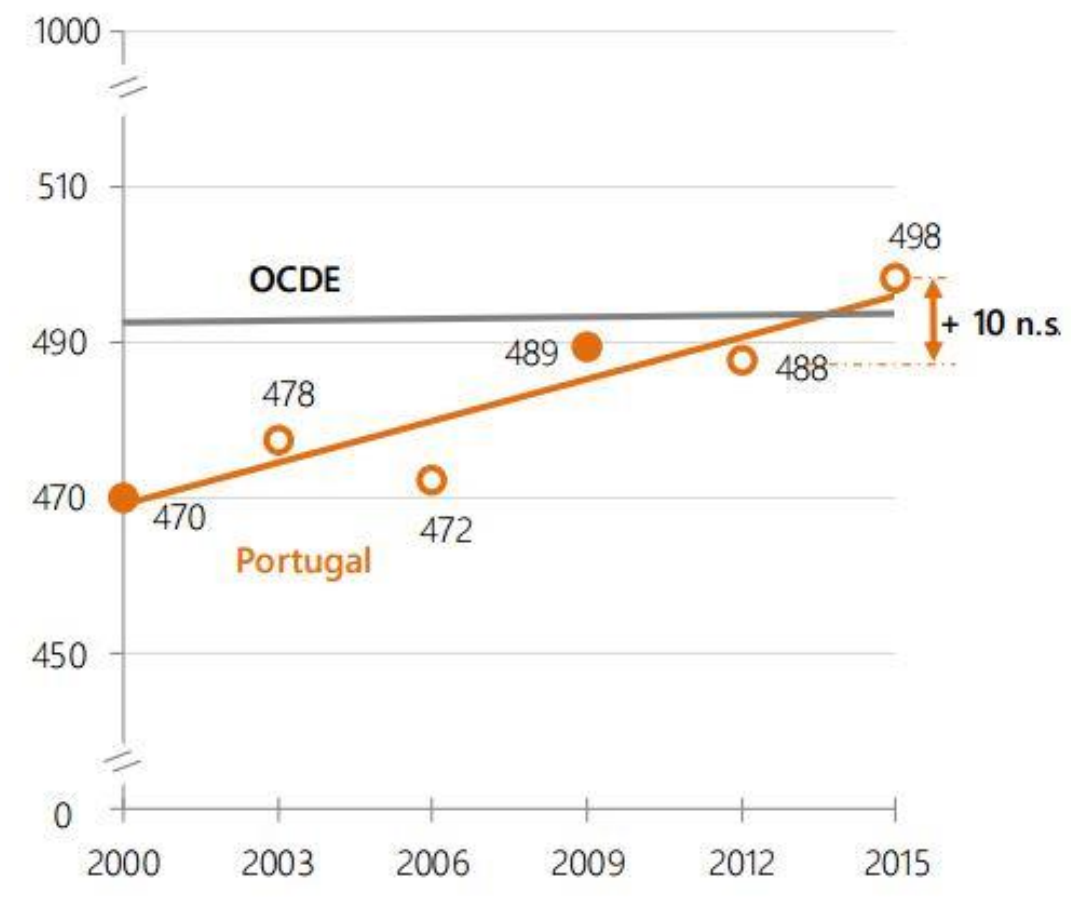

HOW SCHOOL LIBRARIES CONTRIBUTED TO THIS PROGRESS Guiding documents 
Presently, SLN has three main documents that provide guidance to the work of school libraries: the 2014-2020 Strategic Framework; the School Library Evaluation Model and the learning standards Learning with the school library. They are linked among them, and very coherent. They establish high standards for school libraries and stimulate a process of continuous growth and improvement.

The Strategic Framework produced by the SLN defines a set of quality standards for school libraries to achieve within the time frame of 2014-2020, determined by the Europe 2020 Strategy that Portugal and the Ministry of Education subscribed. The establishment of these standards guides the action of school libraries.

The areas of the Evaluation Model (A. Curriculum, literacy and learning; B. Reading literacy; C. Projects and partnerships; D. School library management) proceed from the standards established in the Strategic Framework and it is expected that, at the end of the evaluation cycle 2014-2017 all the evaluated libraries present an evaluation equal to or higher than 3 (in a scale of 1 to 4 ).

Finally the main objectives of Learning with the school library are to associate reading, media, technologies and working with information in curricular or extracurricular learning situations, through the collaboration of school libraries with teachers/educators and to provide school libraries with a guidance tool that can contribute to the extension of their role, influence and impact on educational success.

This consistent guidance has proved to be of great importance in the process of continuous improvement of school libraries and their impact on student reading performance and learning.

\section{Networks within a Network}

However, the existence of good guiding documents would not be enough to explain the success of Portuguese school libraries. The fact that libraries form a network is a decisive success factor. On the top of this network is a central office in the Ministry of Education led by a national coordinator assisted by a small number of technical advisors. At an intermediate level there are around forty regional coordinators who accompany and monitor the work of school libraries in districts and municipalities. These regional coordinators guarantee that teacher librarians really do understand and put in practice the central orientations and provide training and support. This way, it is possible to maintain an evenness in the level of work performed by school libraries that otherwise would be impossible.

At the municipality level there are smaller libraries networks, led by the regional coordinators and the public libraries, in which all teacher librarians take part. These regional networks implement several collective initiatives, namely thematic meetings, training and cooperation projects, involving schools, public libraries, museums and other community institutions.

This is a very sustained and sustainable network, which makes every problem rather easier to solve.

\section{Stimulating and Spreading the News}

Despite being a network, one of the problems we have met is the lack of information each library has about the work done by other school libraries. Every library has its online channels, every regional network has a website, but, nevertheless, that didn't look to be enough for each one to know about what others are doing and how they are doing it. In most regional meetings, some of the schedule is dedicated to good practice sharing and it has become usual to invite teacher librarians who develop excellent projects in the area related to the meeting's theme.

So, in 2013, the SLN decided to start disseminating best practices in its webpage. Regional coordinators were involved in the election of the practices to be publicized, following a given format. School libraries have to fill in a form with the description of the practice and send all the materials they consider relevant. They also produce a presentation video. Practices are organized according to different categories: curriculum collaboration; reading; information literacy; extracurricular activity support; marketing and advocacy; digital training; playful activity; and so on.

It is also considered the main target users of each practice: students; students and teachers; teachers; parents; whole school; educational community.

A database was built and thus, every teacher librarian can search a practice that matches his/her needs. An inspiring example can give birth to something similar or to something that, due to the necessary 
adaptations, ends up to be utterly different. But the important thing is that good examples are available and easily usable.

\section{Picture 1. Good practices database}

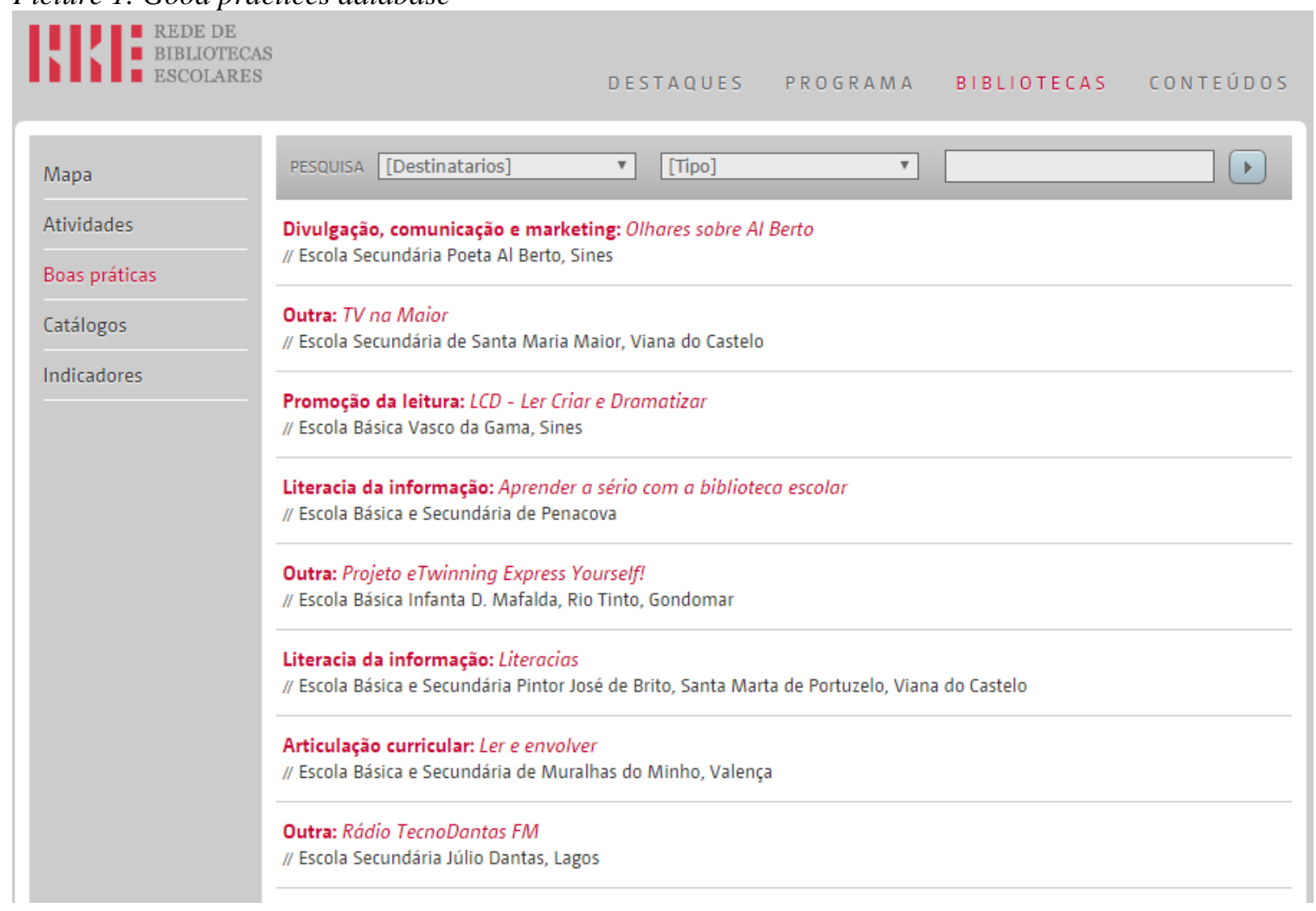

\section{BEST PRACTICE - EXAMPLES}

These are some examples of practices that have been disseminated in the SLN webpage. Through them it is possible to meet all the subthemes suggested by IASL: School library programs transcend the four walls; School library programs cross school borders; School library resources cross media; School library instruction crosses curricula and literacies; School library programs serve all students; Learning occurs anywhere, any time.

- $\quad$ Crossing Borders - Joint Multicultural Campaign

This project is included in the category curriculum collaboration and its target are students and teachers.

It is related to Comenius project - Slodic (School Libraries: Open Doors to Intercultural Competences). It happened in two phases, the first in Portugal and the second one in Denmark. All the work was mainly developed in the school library, articulating with the English teachers. The curriculum areas involved were English and Citizenship (the value of multiculturality).

- $\quad$ Reading Meetings

This project is included in the category Reading and its target is the educational community. It consists of monthly reading meetings. Each meating is about a theme. These very participated reading sessions that occur after dinner, often in rather cold evenings, have strengthened the links of the school library and of the school itself with the families and with the educational community. Books are in the center of the interaction that occurs as they allow reading and 
sharing texts among the participants, they provide models to be followed and they value the act of reading.

- $\quad$ TV na Maior

This project is included in the media literacy work of the school library and its target is the whole school.

It consists in the creation of a school TV channel that transmits news, documentaries, interviews and promotional spots about books.

The project is being developed in collaboration between the school library and the teachers and students involved and has the support of two professional journalists who are training students in journalistic writing, filming, video and sound editing.

The articulation with the school libraries will allow students to develop competencies in media and information literacy, digital literacy, reading and writing and simultaneously promote their critical thinking, creativity and innovation, autonomy and responsibility, safe use of digital tools and environments, problem solving, collaboration and communication.

The project applies Learning with the school library in secondary education and is considered by teachers and students very important to active citizenship and to independent lifelong learning.

- Reading... Communicating... Integrating

This project is included in the curriculum collaboration category and its target is the whole school.

It involves the collaboration between Special Education teachers, teachers of different areas and the school library.

The aim is to reinforce the formative role of the school library in cognitive, informational and artistic skills of children and young people with special needs, allowing them a full integration in the school and in the community.

- $\quad$ Reading and involving

This project is included in the curriculum collaboration category and its target are the students.

The school library team selects texts connected to classroom content and publishes them in the library website in a section dedicated to the project. Each text is accompanied by an online questionnaire designed to develop reading competences. The teacher of the involved disciplines give students the URL and they do the activities autonomously in the established time. They can do it in the school library or in the classroom. This is done through Google forms and allows the school library to give feedback to the teachers of the answers given, so that they can discuss them with their students.

\section{CONCLUSION}

Through the feedback given by regional coordinators we have the perception that the publicizing of these practices has a positive effect on school libraries. Some of these practices are quite ellaborate, but others are rather simple and teacher librarians feel more at ease to show their good ideas, however simple they may be.

Some of the libraries reproduce the practices with little changes and become more intervenient and active in the context of their school. Others go beyond that and get stimulated in their creativity, making way to the appearance of new good practices.

The fact that they are centralized in the SLN website, that is very often visited by teacher librarians, is of decisive importance. Finally the database organized by categories facilitates the search.

So, the publicizing of good practices by the SLN is a good practice itself.

\section{REFERENCES}

Portugal. Rede de Bibliotecas Escolares (2013). Programa Rede de Bibliotecas Escolares. Quadro estratégico: 2014-2020. $\quad$ Retrieved May 13, 2017 from http://www.rbe.mec.pt/np4/np4/?newsId=1048\&fileName=978_972_742_366_8.pdf 
Portugal. Rede de Bibliotecas Escolares (2012). Modelo de avaliação da biblioteca escolar 2014-2017. Retrieved May 13, 2017 from http://www.rbe.mec.pt/np4/file/1047/978_972_742_365_1.pdf

Portugal. Rede de Bibliotecas Escolares (2017). Aprender com a biblioteca escolar. 2. ${ }^{\text {a }}$ edição, revista e aumentada / coord. Elsa Conde, Isabel Mendinhos e Paula Correia. Retrieved May 13, 2017 from http://www.rbe.mec.pt/np4/file/1906/referencial_2017.pdf

Portugal. Instituto de Avaliação Educativa, IP (2016). PISA Portugal - Apresentação dos resultados nacionais. Coord. João Marôco. Retrieved May 13, 2017 from http://www.iave.pt/np4/file/310/Apresenta_oPISA2015.pdf

OECD (2016), PISA 2015 Results (Volume I): Excellence and equity in education. Paris, France: PISA, OECD Publishing. Retrieved May 13, 2017 from http://dx.doi.org/10.1787/9789264266490-en 